Historic, Archive Document

Do not assume content reflects current scientific knowledge, policies, or practices. 


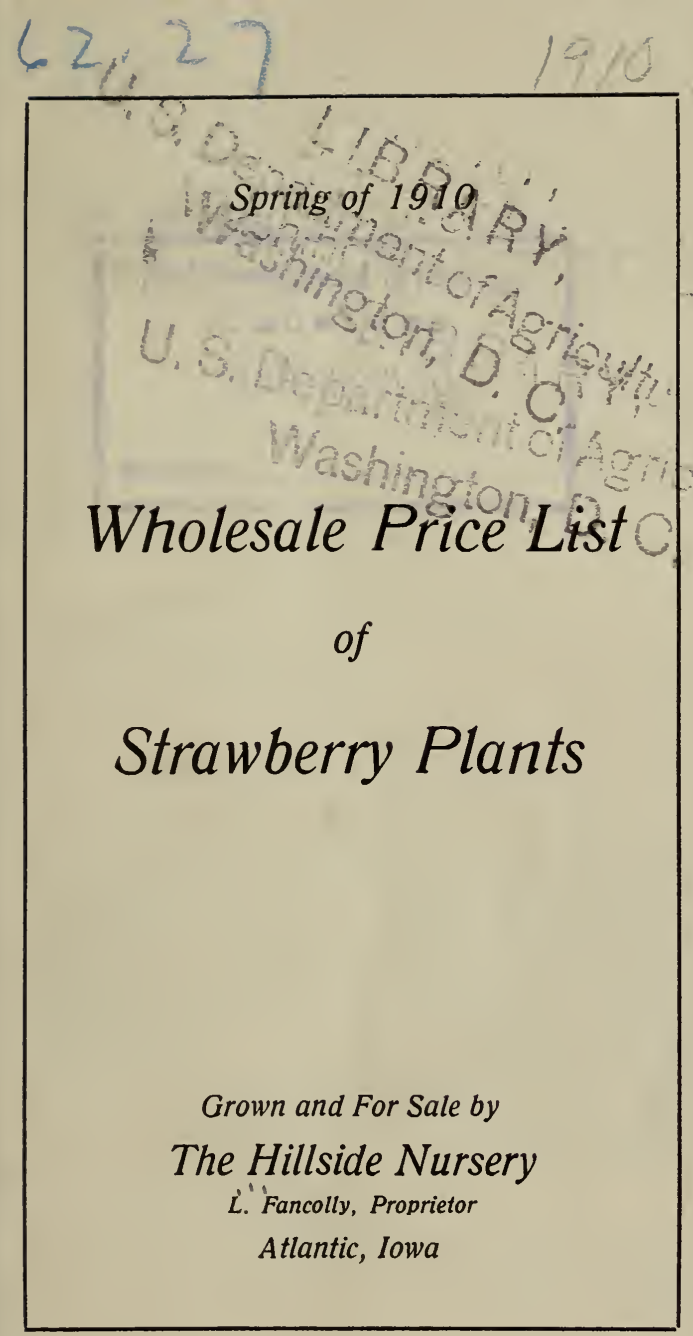


In submitting our price list of strawberry plants, it gives us pleasure to return thanks for the liberal patronage accorded us during the past year, and we assure you of our continued and increasing effort to maintain the high reputation which we have gained during our business period.

Our stock this spring is large and very complete, and in fine condition. Our prices are as low we assure you, as good stock can be grown for.

All questions pertaining to our line of business will be cheerfully answered.

Respectfully yours,

THE HILISIDE NURSERY,

L. Fancolly, Prop.

\section{State of lowa}

Certificate of Nurserj Inspection

Office of the State Entomologist, Ames, Iowa.

THIS IS TO CERTIFY, That in accordance with Chapter 53 of the Acts of the Twentyseventh General Assembly (Code Section 2575a51), the nursery stock for sale by L. Fancolly, of Atlantic, Iowa, has been inspected by a duly authorized inspector and has been found apparently free from dangerously injurious insects and plant diseases.

H. E. SUMMERS

State Entomologist

This certificate is invalid after July 1 , 1910. Certificate No. 68 Dated August 14, 1909. 


\section{Price List of Strawberry Plants}

By Express at Purchaser's Expense

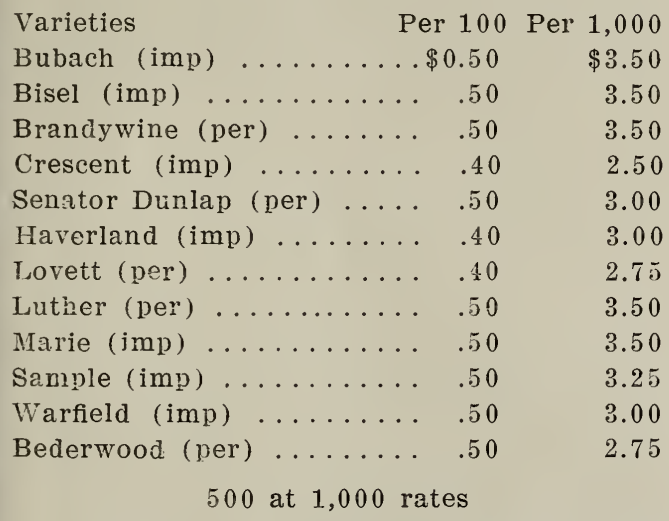

Nurserymen and dealers wanting larger quantities, write for prices.

\section{Rhubarb}

Divided roots per dozen, $\$ 0.50$; per 100 $\$ 2.00$; per $1,000, \$ 15.00$. By express at purchaser's expense.

\section{References:}

Atlantic National Bank Any Bank or Business House in Atlantic Dunn's Mercantile Agency 


\section{Terms and Conditions}

\section{Shipping}

We dig and ship plants as soon as the weather will permit in the spring. Parties ordering, should indicate if wanted by freight or express, also route. If no directions are given, we will forward to the best of our judgment, without assuming responsibility, after consignment to the purchaser.

\section{Terms}

Cash. When desired, we will allow usual terms of credit to responsible nurserymen. All bills not paid by June 1st subject to sightdraft without notice.

\section{Packing}

Prices in this list include boxing, packing and delivery to the freight or express office in Atlantic, Certificate of inspection will be furnished with each shipment. All plants are nicely trimmed, tied in neat bunches of 25 each and packed in light boxes, with clean moss.

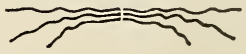




\section{General}

Varieties marked "imp" are imperfect, and will not bear fruit unless a variety marked "per" is planted with them, as fertilizer.

\section{About Ordering}

It will be to your interest, as well as ours, to order early, as every year, we have been short on plants and have had to refuse all late orders.

You are also assured of better selection, and better service, as our stock is more complete, and we are better able to handle orders earlier in the season.

\section{Shipments}

- For longer distances, it is much better to order plants sent by express, as they will arrive in much better condition, than if they traveled by the slower freight. Also express companies, make better rates on plants and seeds, than they do on any other form of merchandise. 


\section{The Hilliside Nursery}

Retail Grounds one mile east of courthouse, opposite the old McGeehon nursery, near main line of Rock Island railway.

Plant and fruit farm three miles east of court house, Atlantic, visible from Rock Island trains. 
